DOI

\title{
ЗАСТОСУВАННЯ ІНТЕРАКТИВНОГО МЕТОДУ “МОЗКОВОГО ШТУРМУ” У НАВЧАЛЬНОМУ ПРОЦЕСІ
}

т. В. Мергель

ДВНЗ “Івано-Франківський національний медичний університет”

\section{APPLICATION OF “BRAINSTORMING” INTERACTIVE METHOD IN EDUCATIONAL PROCESS}

T. V. Merhel

\section{SHEI “Ivano-Frankivsk National Medical University”}

\begin{abstract}
Робота присвячена вивченню та впровадженню інтерактивного методу навчання “мозковий штурм” у процес викладання тематичних занять з внутрішньої медицини для студентів V курсу медичного факультету.

У студентів-медиків старших курсів впровадження в процес освітньої технології “мозкового штурму” сприяє: розвитку творчого підходу до вирішення проблеми, формуванню вмінь, оцінюванню ситуації, вибору та організації пошуку основної інформації, виробленню клінічного мислення, формуванню навичок роботи в групі, комунікабельності, толерантності, розвитку креативності, впевненості в собі, виробленню вмінь розробляти багатоваріантні підходи у вирішенні клінічної ситуації, виробленню вміння висловлювати власну думку, виробленню навичок роботи в колективі, формуванню вмінь всебічного аналізу ситуації, набуттю навичок до конструктивної критики, формуванню вміння вибрати найоптимальніший варіант у складній клінічній ситуації, набуттю навичок використання теоретичного матеріалу для аналізу практичних проблем.
\end{abstract}

The work is devoted to the study of results of "brainstorming" interactive method introduction of studies in the process of thematic classes in internal medicine for the $5^{\text {th }}$ grade students of medical department.

The introduction of "brainstorming" educational technology to the process promotes in senior medical students: development of creative approach to problems solving, developing of skills of assessing of the situation, selecting and organizing of basic information, development of clinical thinking, the skills of group work, communication skills, tolerance, development of creativity, self-confidence, skills to work out multivariate approaches to solving of a clinical situation, the ability to express their own opinion, skills of working in the team, developing abilities of comprehensive situation analysis, skills of constructive criticism, forming the ability to choose the best option in a difficult clinical situation, skills to use theoretical material for analyzing of practical problems.

Вступ. Пріоритетом сьогодення стає впровадження у навчальний процес засобів інформаційнокомунікаційних технологій та об’єднання їх на організаційному, методичному та технологічному рівнях [2]. Важливою передумовою підвищення якості підготовки майбутніх фахівців $є$ розвиток і вдосконалення форм та методів контролю навчальних досягнень, який реалізує зворотний зв’язок у навчанні, забезпечуючи можливість оперативного регулювання й коригування цього процесу [1] Відповідно до Концепції розвитку вищої медичної освіти, реформування національної системи охорони здоров’я потребує підготовки нового покоління висококваліфікованих медичних працівників, здатних до творчої праці, освоєння і впровадження наукових та інформаційних технологій, конкурентоспроможності на ринку праці. Формування сучасної моделі підготовки майбутніх лікарів,

\footnotetext{
(c) Т. В. Мергель
}

здатних до конструктивно-критичного мислення, передбачає впровадження у навчальний процес сучасних педагогічних та наукових інновацій відповідно до світових стандартів, зокрема інтерактивних методів навчання. Іноваційна педагогічна діяльність заснована на осмисленні практичного педагогічного досвіду, орієнтована на зміну й розвиток навчально-виховного процесу з метою досягнення вищих результатів, одержання нового знання, формування якісно іншої педагогічної практики. Головними особливостями інноваційної педагогічної діяльності є: особистісний підхід, творчий дослідно-експериментальний характер, стійка мотивованість на пошук нового в організації навчально-виховного процесу [4]. Саме застосування інтерактивних методів навчання сприяє інтенсифікації та оптимізації навчального процесу і передбачає наступні ідеї: активізація розумової діяльності студентів; актуалізація опорних знань; 
індивідуалізація навчального процесу; знаходження раціональних шляхів розв'язання проблем, формування навичок проектної діяльності, самостійної роботи, творчих робіт [2].

Основна частина. Варіантом інтерактивного, іноваційного навчання $є$ метод “мозкового штурму”, який відповідає основним медичним компетенціям, підвищує ефективність та результативність навчання за його використання на етапах навчального процесу. Різні засоби підходів до діагностики та лікування, проведення, вирішення проблем з використанням мозкового штурму реалізують більш ефективну підготовку до практичної діяльності лікаря зі спеціальності “Терапія” завдяки формуванню системи професійних знань, вмінь та практичних навичок, науково-практичного самовдосконалення, комунікативних якостей особистості фахівця та професійної соціальної активності.

Метою роботи було застосування інтерактивного методу “мозкового штурму” для підвищення навчально-пізнавальної діяльності студентівмедиків при вивченні дисципліни “Внутрішня медицина” у ДВНЗ “Івано-Франківський національний медичний університет”.

“Мозковий штурм” - це оперативний метод вирішення проблеми на основі стимулювання творчої активності, при якому учасникам обговорення пропонують висловити якомога більше варіантів вирішення, в тому числі найнезвичайніших, а потім із загального числа ідей відбирають найвдаліші, які можуть бути використані на практиці. Метод широко використовується для пошуку нетрадиційного вирішення завдань і $€$ методом експертного оцінювання. Основними навчальними цілями методу мозкової атаки є: набуття навичок використання теоретичного матерілу для аналізу практичних проблем; вироблення вмінь формулювання питання і запиту; вироблення вмінь розробляти багатоваріантні підходи до реалізації плану дій; формування самостійно приймати рішення в умовах невизначеності; формування навичок та прийомів всебічного аналізу ситуацій, прогнозування способів їх розвитку.

Виховними цілями мозкового штурму є: розвиток працьовитості, розвиток креативності, формування здатності до конкурентної спроможності, формування готовності взяти на себе відповідальність за результати власного аналізу ситуації і за роботу всієї групи, формування впевненості в собі, формування потреби в досягненні, формування навичок роботи в групі, формування навичок комунікативної культури, формування соціально активної і жит- тєво компетентної особистості, здатної до саморозвитку, самовдосконалення і самореалізації. Метод “мозкового штурму” - це трьохетапна процедура розв’ язання задачі: на першому етапі генеруються ідеї, на другому ці ж ідеї аналізуються, систематизуються й розвиваються. На першій стадії забороняється обговорювати висунуті ідеї та пропозиції (вважається, що критичні зауваження переривають творчий процес, заважають висуванню нових ідей). На цій стадії перевага надається кількості, а не якості ідей, що висуваються. На другій стадії студенти повинні розвинути висунуті ідеї: в будь-якій 3 них можна знайти раціональне зерно. Звичайно, учасники концентрують свою увагу перш за все на позитивних сторонах ідей. Саме їх вони і намагаються розвинути. Тому додаткові ідеї, що висуваються в процесі обговорення, можуть базуватися на ідеях інших учасників або, навпаки, бути для них фундаментом, каталізатором. Значний ефект дає комбінування ідей шляхом складання переліку всіх запропонованих варіантів виконання функції, що аналізується, з зазначенням переваг і недоліків кожного з варіантів. При обговоренні цього переліку спеціалістами різних професій виникають нові, більш оригінальні та плідні ідеї, засновані на комбінаціях раніше висунутих пропозицій.

Перед початком розгляду проблеми, яка має бути вирішена методом “мозкового штурму”, необхідно провести розминку, яка допоможе учасникам налаштуватися на потрібну манеру спілкування, тип мислення, швидкість реакції тощо. Альтернативним варіантом розминки є робота в режимі брейнстормінгу, коли викладач пропонує блок тренінгових запитань, на які учасники висловлюють свої ідеї без обмежень. Запитання повинні бути направлені на генерацію незвичайних, навіть утопічних ідей. Після розминки повинна активуватись і запрацювати творча права півкуля мозку. На розминку відводиться близько 20 хвилин. Для реалізації методу “мозкового штурму” викладач організовує групу учасників (уся клінічна група - 8-10 студентів), щоб вони знаходилися на рівнозначній відстані від викладача. Викладач пропонує студентам вибрати модератора групи (модератор - той, хто буде слідкувати за правилами мозкового штурму на всіх його етапах, записувати ідеї (за допомогою малюнків, ключових слів, своїх позначок), пропонувати свої). I етап - організаційні питання, постановка проблеми. Це попередній, але дуже важливий етап. Для успішного мозкового штурму викладач якомога конкретніше формулює завдання. Це необхідно 
для того, щоб направити потік своїх думок у певне русло, інакше ідеї, що генеруються, можуть бути вельми далекі від вирішення конкретної проблеми. II етап - генерування ідей. Основний етап, від якого багато в чому залежить успіх всього мозкового штурму. Тому дуже важливо дотримуватися правил для цього етапу: “генерування” ідей має відбуватися невимушено, слід висловлювати будь-які, нехай і явно помилкові або виразно фантастичні ідеї; обгрунтування не потрібне; всі до одної ідеї записуються модератором на дошці або в протоколі. Запис урівнює всі ідеї і робить їх належними всій команді; записувати ідеї та пропозиції доти, поки студенти говорять по темі та не повторюються; не можна примушувати; кожен може висловитися по два, три або чотири рази. Але пріоритет мають учасники, які ще не висловлювалися. Коли кожний висловлюється, у решти з'являються нові думки, асоціативні образи; у процесі генерування ідей заборонено будь-яку критику. Головне - не якість, а кількість ідей! Бажано, щоб ідея, висунута одним із учасників, підхоплювалася і розвивалася іншими. III етап - експертиза, або оцінка ідей. Саме цей етап дозволяє виділити найбільш цінні ідеї і дати остаточний результат мозкового штурму. На цьому етапі, на відміну від другого, оцінка не обмежується, а навпаки, вітається. Методи аналізу та оцінки ідей можуть бути дуже різними. У процесі експертизи слід уважно обмірковувати всі ідеї, навіть ті, котрі видаються відверто абсурдними. Перед тим, як почати вибір потрібної ідеї, необхідно видалити ті, що повторюються, не відносяться до теми або проблеми. Розставити пріоритети (у відповідності 3 тими критеріями, які для нас найбільш значимі при вирішенні даної задачі). Найпереспективніші ідеї проробляються. Успішність цього етапу прямо залежить від того, наскільки “однаково” учасники розуміють критерії відбору та оцінки ідей. На закінчення роботи доцільно виділити деякий час для того, щоб учасники довільно могли обмінятися враженнями про свою роботу. Викладач може запитати студентів, як вони оцінюють ефективність діяльності на даному занятті. При цьому всі разом можуть розмірковувати про те, які були негативні моменти та як закріпити позитивний ефект.

Метод мозкового штурму найкраще застосовувати для розв’язання завдань, які не є точними або спеціальними, і аж ніяк не підходить для розв’язання дискусійних питань - адже кожен 3 дискутантів зобов’язаний обгрунтувати свою позицію, що входить у суперечність із умовами brain- storming. Мозковий штурм не заміняє мислення, він може його лише активізувати!

Таким чином, інтерактивний метод навчання за типом “мозкового штурму” дозволяє захопити в активну пошукову, практичну діяльність максимальну кількість студентів-медиків. Застосування цього методу можливе на різних етапах практичного навчального заняття, для введення нових знань, закріплення набутих вмінь та знань, для проведення проміжного контролю якості засвоєних знань, закріплення вмінь та знань на загальному рівні конкретної теми заняття. 3 допомогою цього методу досягається $\alpha-4$ рівень професійної підготовки, який ще називають творчим, оскільки створюються умови для самостійного знаходження студентом нових для нього знань чи способів дії, а також розширення таксономії параметрів - рівнів засвоєння інформації з 4-х до 5-ти і включення компетенції і компетентностей в якості складових 4-го і 5-го рівнів засвоєння інформації, а саме: володіння предметними і операційними знаннями, вміннями, навичками; здатність і готовність до їх практичного застосування; впевненість в дії; відповідальність за результати діяльності.

Переваги методу: забезпечення кожному члену групи “мозкового штурму” рівної участі в обговоренні проблеми та висуванні ідей; однакова продуктивність на будь-якій стадії процесу ухвалення рішення; можливість фіксації та постійного запису всіх висунутих ідей; сприятливі умови для виникнення ефекту “ланцюгової реакції” ідей.

Недоліки методу: можливість домінування одного чи двох лідерів - найбільш активних учасників групи; імовірність “зациклення” на однотипній ідеї; необхідність певного рівня компетентності та наявності представників різних спеціальностей у складі однієї групи; обмеженість часу на проведення. Інтерактивний метод навчання “мозковий штурм” є дієвим і ефективним для підвищення показників успішності навчання студентів і згідно 3 отриманими результатами може бути рекомендованим до використання на практичних заняттях 3 внутрішньої медицини.

Висновки. Застосування інтерактивного методу “мозкового штурму” можна і доцільно використовувати поряд з традиційними методами навчання у вищих медичних навчальних закладах при викладанні практичних дисциплін. Метод мозкової атаки є цікавою активною формою навчання, що мотивує інтерес до теми, дисципліни загалом, підвищує навчально-пізнавальну діяльність студентів, 
сприяє розвитку творчого мислення, вміння приймати конструктивні рішення. Використання цього методу дозволяє студентам ширше поглянути на проблему, вчить їх конструктивно сприймати

\section{Список літератури}

1. Войцещук Л. Є. Інтерактивне навчання - технологія сучасного навчання / Л. Є. Войцещук // Вісн. Запорізького нац. ун-ту. - 2011. - № 3 (15). - С. 46 - 49.

2. 3 досвіду впровадження кредитно-модульної системи організації навчального процесу в ІваноФранківському національному медичному університеті / М. М. Рожко, Г. М. Ерстенюк, В. В. Капечук [та iн.] // Впровадження нових технологій за кредитномодульної системи організації навчального процесу BM(Ф)НЗ III-IV рівнів акредитації : матеріали Всеукр. навч.-наук. конф. присвяченої 55-річчю Тернопільського державного медичного університету імені думки оточуючих, глибше обгрунтовувати власний погляд на проблему, обумовлює розуміння багатоваріантності можливих рішень, що є необхідним для майбутніх лікарів.

I. Я. Горбачевського МО3 України (Тернопіль, 26-27 квітня 2012 р.). - Тернопіль : Укрмедкнига, 2012. С. $57-59$.

3. Неловкіна-Берналь О. А. Педагогічні умови формування професійної спрямованості студентів медичних спеціальностей / О. А. Неловкіна-Берналь // Вісник ЛНУ імені Тараса Шевченка. - 2010. - Ч. 1, № 10 (197). C. 12-21.

4. Шамис В. А. Активные методы обучения в вузе / В. А. Шамис // Сибирский торгово-экономический журнал. - 2011. - № 14. - С. 136-144.

Отримано 08.10.15 